\title{
Nasionalisme Organisasi Mahasiswa Islam dalam Menangkal Radikalisme di Institut Agama Islam Negeri (IAIN) Surakarta
}

\author{
Abdulloh Hadziq \\ Institut Agama Islam Negeri Surakarta, Indonesia \\ Jl. Pandawa Pucangan Kartasura Sukoharjo Jawa Tengah \\ Email: hadziq.abdulloh@gmail.com
}

\begin{abstract}
Radicalism in the campus is a crucial problem that it has spread widely among students. This study attempts to elaborate on how Student Islamic Organizations take role and strategy to prevent Radicalism among the students. The type of study is qualitative with Phenomenological Approach. The subjects were PMII, HMI, IMM, and KAMMI. The data were collected by interview, observation, documentation, and focus group discussion. The analysis of the data that was used was phenomenological data analysis by Moustakas. The study states that the roles and strategies of the Student Islamic Organizations of preventing the radicalism are; firstly, there is a responsive curriculum to radicalism within the recruitment or regeneration of the organization that consists of nationalism values and dialogue tradition; secondly, internalizing Islamic values moderately among the students and maximizing the role of senior figures of the organization as role models for both on campus or off campus; Thirdly, the collaboration between the institution and the student organizations.
\end{abstract}

Keyword: Nationalism, Student Islamic Organizations, Radicalism

\begin{abstract}
Abstrak: Persoalan yang cukup krusial di berbagai kampus adalah merebaknya pahampaham radikal yang mulai menyasar mahasiswa di kampus. Adapun tujuan dari penelitian ini adalah untuk mengetahui bagaimana peran dan strategi organisasi Islam kampus dalam membendung arus paham radikal di kalangan mahasiswa IAIN Surakarta. Jenis penelitian ini adalah kualitatif dengan menggunakan pendekatan fenomologi. Sasaran penelitian yang dipilih adalah organisai mahasiswa Islam kampus seperti PMII, HMI, IMM, dan KAMMI. Tekhnik pengumpulan data menggunakan wawancara, observasi, dokumentasi dan FGD. Adapun Analisis data yang digunakan dalam penelitian ini adalah analisis data fenomenologi, yang digunakan Moustakas. Hasil penelitian ini menyatakan bahwasanya peran dan strategi organisasi mahasiswa Islam kampus yang dilakukan dalam menangkal radikalisme adalah : Pertama, Kurikulum Kaderisasi Responsif Radikalisme dengan cara memasukkan materi tentang nilai-nilai keIndonesiaan dan kebangsaan, mentradisikan dialog dalam setiap kegiatan. Kedua, Internalisasi nilai-nilai Islam ramah dengan cara mengkampanyekan moderasi Islam, memaksimalkan peran figure organisasi sebagai tauladan baik figure senior dalam kampus atau diluar kampus. Ketiga, Kemitraan dengan Perguruan Tinggi, berafiliasi dengan kegiatan organisasi intra yang ada di dalam kampus.
\end{abstract}

Kata Kunci: Nasionalisme, Organisasi Mahasiswa Islam, Radikalisme 


\section{PENDAHULUAN}

Keberadaan organisasi di kampus menempati peran yang sangat strategis dalam proses pendidikan karakter mahasiswa dalam ruang lingkup kampus dan sekitarnya. Organisasi dalam kapasitasnya sebagai wadah untuk berkreasi bagi mahasiswa dapat berkembang secara maksimal jika dikawal dengan baik oleh pihak kampus baik dalam hal strategi maupun peranannya dalam mengawal para mahasiswa serta menghadapi berbagai persoalan yang sedang marak terjadi di kampus belakangan ini.

Salah satu yang menjadi persoalan yang cukup krusial di berbagai kampus adalah merebaknya paham-paham radikal yang mulai menyasar mahasiswa di kampus. Persoalan ini jika tidak dihadapi dengan serius dapat menjadi bom waktu yang dapat meledak sewaktu-waktu dan menjadi boomerang bagi kampus itu sendiri. Beberapa contoh yang bisa disebutkan dari kasus ini adalah ditemukannya fenomena radikalisme di berbagai perguruan tinggi umum. Hal ini dapat diketahui dalam penelitian tentang Islam Kampus yang melibatkan 2466 sampel mahasiswa dari berbagai perguruan tinggi di Indonesia. Saat mahasiswa diberi pertanyaan tentang pelaksanaan amar makruf nahi munkar dalam bentuk sweeping tempat yang dikategorikan sebagai sumber maksiat, maka mereka menjawab sebagaimana berikut : kurang lebih sekitar 65\% (1594 responden) mendukung dilaksanakannya sweeping kemaksiatan, sekitar 18\% (446 responden) mendukung sekaligus berpartisipasi aktif dalam kegiatan sweeping. Dan juga, 11\% (268 responden) menyatakan tidak mendukung adanya sweeping, sedangkan sisanya, 6\% (158 responden) tidak menentukan jawabannya tentang pertanyaan tersebut. Selanjutnya, mereka yang menyatakan mendukung adanya sweeping beranggapan sweeping bagian dari perintah agama (88\%), dan mendukung sweeping karena aparat keamanan dianggap tidak mampu menegakkan hukum (4\%), dan terakhir dikarenakan alasan dekadensi moral (8\%) (Fadjar, dkk., 2007: 35).

Data lain yang disampaikan oleh Saifuddin dalam penelitiannya yang berjudul Radikalisme di kalangan mahasiswa di Jogjakarta menghasilkan narasi bahwa perguruan tinggi umum lebih mudah dijadikan sebagai tempat rekrutmen gerakan radikal, sementara perguruan tinggi yang berbasis keagamaan lebih sulit dalam upaya radikalisasi. Jika ternyata fakta menunjukkan bahwa gerakan radikal juga sudah marak dan tumbuh subur di kampus berbasis keagamaan, maka ini membuktikan dua hal. Pertama, terjadi perubahan di dalam perguruan tinggi berbasis keagamaan itu sendiri. Kedua, adanya metamorfosa bentuk serta strategi gerakan di internal gerakan-gerakan radikal itu sendiri (Saifuddin, 2011: 2829).

Di samping itu, adanya upaya konversi dari Institut Agama Islam Negeri (IAIN) ke Universitas Islam Negeri (UIN) juga membuka peluang bagi alumnialumni yang berasal dari SMU/SMK untuk dapat menjadi bagian dari mahasiswa perguruan tinggi keagamaan tersebut. Jika dahulu sebagian besar calon mahasiswa IAIN merupakan alumni dari lulusan madrasah atau pondok pesantren. Selanjutnya ada kebosanan muncul saat materi yang disampaikan tidak berbeda jauh atau bahkan dibawah dari standar mereka sebelumnya. Sehingga, mereka lebih suka mencari buku - buku filsafat, ilmu sosial politik dan semacamnya. Akhirnya, semangat mempelajari agama menjadi menurun dan bahkan kecenderungan mendekati untuk liberal. Dengan demikian, kondisi semacam ini membuat mereka sulit untuk didoktrin menjadi orang militan dan radikal. Sedangkan calon mahasiswa yang berasal 
dari SMU/SMK karena sebelumnya banyak belajar tentang ilmu umum (non agama), dan mereka baru menemukan ghirah atau semangat beragamanya di kampus, terlebih saat bertemu dengan aktivis-aktivis lembaga dakwah dan organisasi-organisasi tertentu. Latar belakang inilah yang kemudian menjadi lahan untuk membangun dan membangkitkan sikap militansi keagamaan dalam diri mereka (Saefuddin, 2011: 28-29).

Hal yang sangat mengejutkan adalah keterlibatan salah satu mahasiswa IAIN Surakarta yang diduga terlibat dalam aksi terorisme yang berakhir pada dikeluarkannya yang bersangkutan sebagai mahasiswa IAIN Surakarta. Hal ini menjadi bukti yang sangat kuat bahwa benih-benih paham radikal sudah mulai merambah ke wilayah-wilayah kampus keagamaan atau PTKIN di Indonesia.

Data-data ini menjadi penting bahwa kampus-kampus keagamaan-pun tidak lepas dari sasaran paham-paham radikal yang sekarang sudah mulai merambah dunia kampus. Dalam konteks ini, kehadiran organisasi-organisasi di kampus idealnya turut berkontribusi sesuai dengan perannya dalam menangkal paham-paham radikal yang secara sengaja disusupkan dalam berbagai materi keagamaan yang diajarkan secara terstruktur di dalam maupun di luar kampus. Namun, jika tidak diperhatikan dengan serius, organisasiorganisai yang berkembang bisa saja juga ikut disusupi paham-paham radikal dan menjadi senjata ampuh dalam penyebaran paham-paham radikal.

Dari uraian serta data-data di atas, maka artikel ini akan memfokuskan pada tema nasionalisme organisasi ekstra kampus dalam peranannya sebagai organisasi strategis dalam upaya menangkal radikalisme dikalangan mahasiswa Institut Agama Islam Negeri (IAIN) Surakarta.

\section{KAJIAN TEORI}

\section{Nasionalisme Kebangsaan}

Nation berarti suatu jiwa, suatu asas spiritual. Nation juga dapat diartikan suatu kesatuan solidaritas yang besar, tercipta oleh perasaan pengorbanan yang telah dibuat di masa lampau dan yang oleh manusia-manusia yang bersangkutan bersedia dibuat di masa depan. Nation itu sendiri memiliki masa lampau, namun ia melanjutkan dirinya pada masa kini melalui suatu kenyataan yang jelas, yakni kesepakatan, keinginan yang dikemukakan dengan nyata untuk terus hidup bersama (Masykur, 2011: 61).

Dengan demikian dapat diartikan, Nasionalisme merupakan sebuah paham kebangsaan artinya suatu bangsa mempunyai perasaan cinta tanah air, cinta terhadap bangsanya sendiri. Sedangkan nasionalisme Pancasila adalah paham kebangsaan yang dilandasi jiwa Pancasila adalah paham kebangsaan yang dilandasi jiwa Pancasila. Bangsa Indonesia dapat diartikan menganut wawasan kebangsaan nasionalisme dalam arti luas, bukan paham nasionalisme dalam arti sempit (chauvinisme). Nasionalisme itu sendiri dibedakan menjadi 2, yakni :

1. Nasionalisme dalam arti sempit, yaitu sebuah paham yang menganggap bangsa/ras sendiri lebih unggul sekaligus ada upaya untuk merendahkan bangsa-bangsa lain. Nasionalisme dalam arti sempit juga dikenal dengan istilah chauvinisme.

2. Nasionalisme dalam arti luas, dapat diartikan sebagai sebuah paham yang mencintai bangsanya sendiri akan tetapi tetap menghargai bangsabangsa lain.

Nasionalisme merupakan paham kebangsaan, artinya bahwa suatu bangsa mempunyai perasaan cinta tanah air dan cinta terhadap bangsa sendiri. Nasionalisme Indonesia yaitu sebuah paham yang dilakukan dengan mencintai bangsa Indonesia sekaligus menempatkan 
persatuan, kesatuan, serta kepentingan dan keselamatan bangsa dan negara di atas kepentingan pribadi maupun golongan dengan cara menghargai adanya persamaan harkat-martabat setiap bangsa, sekaligus mengakui dan menghargai kedaulatan setiap bangsa serta menjalin hubungan persahabatan dan kerja sama dengan semua bangsa bangsa yang ada. Secara singkat nasionalisme Indonesia merupakan sebuah paham kebangsaan yang dilandasi atas dasar semangat kemanusiaan (internasionalisme).

Nasionalisme Pancasila adalah paham kebangsaan yang dilandasi jiwa Pancasila. Pada hahikatnya nasionalisme Indonesia tidak boleh dipahami secara sempit sebatas mementingkan atau mengutamakan kelompok, wilayah, atau golongan tertentu dalam diri bangsa Indonesia. Nasionalisme Indonesia juga tidak hanya bersifat mengagungkan bangsa sendiri dan merendahkan bangsa lain (chauvisnisme). Bangsa Indonesia juga sudah menyadari bahwasanya di luar bangsa Indonesia masih terdapat bangsabangsa lain yang juga memiliki hak untuk hidup sama dan sederajat dengan bangsa kita (Junanto, 2013: 11-12).

Di dalam Al-Qur'an terdapat ayat yang menerangkan bahwa setiap manusia harus saling menghormati dan senantiasa mencintai tanah air sebagaimana yang tertuang dalam Q.S. Al-Hujurat ayat 13, sebagai berikut:

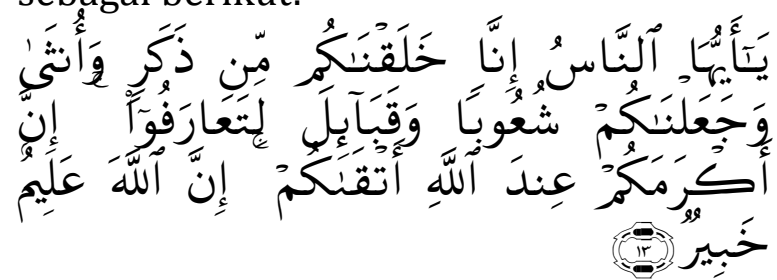

"Hai manusia, Sesungguhnya Kami menciptakan kamu dari seorang laki-laki dan seorang perempuan dan menjadikan kamu berbangsa-bangsa dan bersukusuku supaya kamu saling mengenal. Sesungguhnya orang yang paling mulia diantara kamu di sisi Allah SWT ialah orang yang paling taqwa diantara kamu.
Sesungguhnya Allah SWT Maha mengetahui lagi Maha Mengenal." (Departemen Agama RI, 2011: 517)

Dalam ayat diatas, dapat dijelaskan kemanfaatan sesuatu tidak lepas dari kuatnya pengenalan atas suatu yang dilakukan. Perkenalan itu dibutuhkan untuk saling menarik pelajaran serta pengalaman pihak lain dengan maksud meningkatkan ketaqwaan kepada Allah SWT. Dengan demikian, manusia yang baik dan istimewa adalah yang emiliki akhlak yang baik terhadap Allah SWT, baik terhadap allah atupun sesama makhluk (Shihab, 2012: 615-618)

Junanto (2013: 13) menyatakan, nasionalisme memiliki ciri-ciri sebagai berikut :

1. Cinta tanah air

Hal tersebut dapat ditunjukan dengan penggunaan bahasa Indonesia dengan baik dan benar, pemakaian produksi dalam negeri, dan adanya kemauan memakai pakaian batik yang merupakan ciri khas dari bangsa Indonesia. Seperti halnya, hari wajib menggunakan batik di sekolah merupakan salah satu upaya yang dilakukan guna melestarikan budaya bangsa Indonesia.

2. Rela berkorban untuk kepentingan bangsa dan negara.

Peserta didik membiasakan diri dengan sikap tolong menolong apabila salah satu temannya mengalami kesulitan ataupun musibah. Misalnya, Menjenguk ketika temannya sakit.

3. Menempatkan persatuan, kesatuan, kepentingan dan keselamatan bangsa dan negara diatas kepentingan pribadi maupun golongan.

Saling menghargai dan menghormati adanya perbedaan merupakan salah satu sikap yang dapat mewujudkan persatuan dan kesatuan. Contohnya dengan menghargai pendapat orang lain dan tidak suka berkelahi, serta membiasakan diri untuk toleransi terhadap sesama. 
4. Berjiwa pembaharu

Mempunyai gagasan atau tindakan yang baru untuk membangun masa depan yang baik untuk bangsa dan negara. Contohnya dalam organisasi intra sekolah mempunyai gagasan yang baik untuk memajukan kualitas kegiatan.

5. Tak kenal menyerah

Mempunyai semangat yang tinggi dalam mencari solusi disetiap permasalahan dengan berfikir positif. Contohnya pantang menyerah dalam mengerjakan pekerjaan rumah

Dari uraian di atas dapat disimpulkan bahwa ciri-ciri sikap nasionalisme ialah orang yang mampu mencitai tanah air, rela berkorban, berjiwa pembaharu, tidak kenal menyerah dan mengamalkan sila-sila yang ada di dalam ideologi negara yaitu pancasila.

\section{Konsep dan Radikalisasi di Perguruan Tinggi}

Radikalisme berasal dari bahasa Latin "radix" yang artinya akar, pangkal, bagian bawah, atau bisa juga berarti menyeluruh, habis-habisan dan amat keras untuk menuntut perubahan. Menurut Kamus Besar Bahasa Indonesia (KBBI) radikalisme berarti (1) paham atau aliran yang radikal dalam politik; (2) paham atau aliran yang menginginkan perubahan atau pembaharuan sosial dan politik dengan cara kekerasan atau drastis; (3) sikap ekstrem dalam aliran politik (Depdiknas, 2008: 1158).

Sementara Sartono Kartodirdjo mengungkapkan radikalisme sebagai sebuah "gerakan sosial yang berfungsi menolak secara menyeluruh tertib sosial yang sedang berlangsung yang ditandai oleh kejengkelan moral kuat dalam menentang dan bermusuhan dengan kaum yang memiliki hak-hak istimewa dan berkuasa" (Kartodirdjo, 1985: 38). Dengan demikian, radikalisme merupakan bagian dari gejala umum yang terjadi dalam sebuah masyarakat dengan motif yang beragam, baik sosial, politik, budaya maupun agama, yang ditandai oleh tindakan-tindakan kekerasan, ekstrim, serta anarkis sebagai perwujudan dari penolakan terhadap gejala yang dihadapi.

Selain istilah radikal, sebutan lain yang dipakai untuk melabeli sebuah gerakan yang cenderung anarkis ini yakni fundamentalis, Ekstrim, dan militan. Keempat istilah tersebut pada dasarnya diarahkan pada seseorang atau sekelompok orang dengan nada peyoratif, menghukum, menyudutkan, dan merendahkan akibat perbuatannya yang radikal, eksklusif, tertutup, merasa benar sendiri, dan absolut dalam menghadapi masalah tertentu. Sebab karena itu, jiksa ada kelompok yang dijudge radikal, fundamentalis, ekstrim, atau militant, maka masyarakat pada umumnya akan segera menjauhi atau mengucilkan. Pun, jika ditemukan kelompok masyarakat yang memperlihatkan pola tingkah laku atau pandangan yang ganjil dan aneh, yang kurang sesuai dengan perilaku masyarakat pada umumnya, maka kelompok tersebut akan segera dicap radikal, fundamentalis, Ekstrim , atau militant (Buchor, 1986: 59).

Proses radikalisasi ternyata juga menjangkau kampus khususnya kalangan mahasiswa. Salah satu buktinya adalah tertangkapnya anggota jaringan Pepi Fernando berpendidikan sarjana, dan merupakan lulusan PTKIN. Persentuhan kalangan mahasiswa dengan radikalisme Islam tentu bukan sesuatu yang muncul sendiri di tengah-tengah kampus. Radikalisme itu muncul karena adanya proses komunikasi dengan jaringanjaringan radikal di luar kampus. Dengan demikian, gerakan-gerakan radikal yang selama ini telah ada mencoba membuat metamorfosa dengan merekrut mahasiswa, sebagai kalangan terdidik.

Sesungguhnya, kemunculan gerakan radikalisme dan kelahiran kelompok 
fundamentalisme dalam Islam terdapat dua faktor, yaitu:

a. Faktor internal

Dalam tataran internal gerakan fundamentalisme muncul karena adanya legitimasi teks keagamaan. Kelempok tertentu dalam melakukan tindakan "perlawanan" itu sering kali menggunakan legitimasi teks secara formalitas (baik teks keagamaan maupun teks "cultural") sebagai penopangnya. Kasus gerakan "ekstrimisme Islam" yang merebak hampir di penjuru kawasan negaranegara mayoritas Islam (termasuk Indonesia) juga menggunakan teksteks keIslaman (Al-Quran, hadits dan classical sources "kitab kuning") sebagai basis legitimasi teologis, karena memang teks tersebut secara tekstual ada yang mendukung terhadap sikap-sikap eksklusivisme dan ekstrimisme ini (Al-Qurtuby, 2009: 49), seperti ayat-ayat yang menunjukkan perintah untuk berperang seperti;

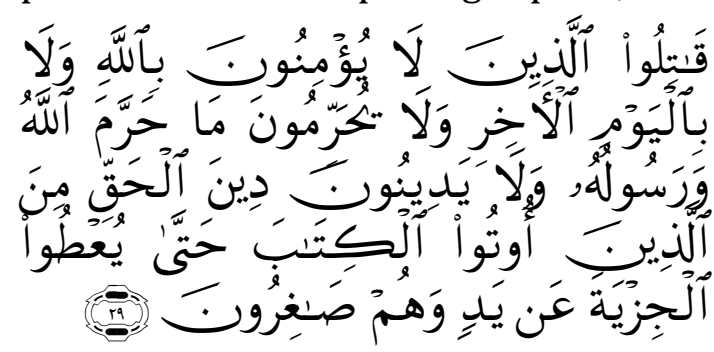

"Perangilah orang-orang yang tidak beriman kepada Allah dan tidak (pula) kepada hari Kemudian, dan mereka tidak mengharamkan apa yang diharamkan oleh Allah dan Rasul-Nya dan tidak beragama dengan agama yang benar (agama Allah), (Yaitu orang-orang) yang diberikan Al-Kitab kepada mereka, sampai mereka membayar jizyah dengan patuh sedang mereka dalam Keadaan tunduk (Q.S. Attaubah: 29).

Menurut gerakan kaum radikal, hal ini sebagai pelopor bentuk upaya tindak kekerasan dengan dalih menjalankan syari'at, bentuk memerangi kepada setiap orang yang tidak beriman kepada Allah dan lainnya. Tidak sebatas itu, kelompok fundamentalis dengan bentuk radikal juga acap kali menafsirkan teks-teks keIslaman menurut "cita rasa" mereka sendiri tanpa mempertimbangkan kontekstualisasi dan aspek historisitas dari teks tersebut, dampaknya banyak fatwa yang berlawanan dengan hakhak kemanusiaan yang Universal dan bertentangan dengan emansipatoris Islam sebagai agama pembebas manusia dari sebuah belenggu hegemoni. Teks-teks keIslaman yang sering kali di tafsirkan secara bias itu adalah tentang perbudakan, status non-muslim dan bagaimana eksistensi perempuan.

b. Faktor eksternal

Faktor eksternal terdiri dari beberapa sebab diantaranya: pertama, dari aspek ekonomi-politik, kekuasaan depostik pemerintah yang cenderung menyeleweng dari nilai-nilai luhur fundamental Islam. Itu artinya, rezim di negara-negara berpenduduk Islam gagal menjalankan nilai-nilai idealistik Islam. Rezim-rezim itu bukan menjadi pelayan rakyat, sebaliknya berkuasa dengan sewenang-wenang bahkan menyengsarakan rakyat. Penjajahan Barat yang serakah, menghancurkan serta sekuler justru datang belakangan, terutama setelah ide kapitalisme global dan neokapitalisme muncul dan menjadi pemenang. Satu ideologi yang kemudian mencari daerah jajahan untuk dijadikan "pasar baru". Industrialisasi dan ekonomisasi pasar baru yang dijalankan dengan cara-cara berperang inilah yang sekarang mengejawantah hingga melanggengkan kehadiran fundamentalisme Islam. Karena itu, fundamentalisme dalam Islam bukan lahir karena romantisme tanah (seperti Yahudi), romantisme teks (seperti kaum bibliolatery), maupun melawan industrialisasi (seperti kristen eropa). Selebihnya, ia 
hadir karena kesadaran akan pentingnya realisasi pesan-pesan idealistik Islam yang tak dijalankan oleh para rejim-rejim penguasa dan baru berkelindan dengan faktor-faktor eksternal yaitu ketidakadilan global (Haryono, 2006: 102).

Kedua, faktor budaya, faktor ini menekankan pada budaya barat yang mendominasi kehidupan saat ini, budaya sekularisme yang dianggap sebagai musuh besar yang harus dihilangkan dari bumi. Ketiga, faktor sosial politik, pemerintah yang kurang tegas dalam mengendalikan masalah teroris ini juga dapat dijadikan sebagai salah satu faktor masih maraknya radikalisme di kalangan umat Islam (Al-Qurtuby, 2009: 59 - 60).

Radikalisme dapat dilahirkan dari penganut agama apa saja dan di mana saja. Hal ini tidak berarti setiap agama mengajarkan kekerasan. Justru sebaliknya, setiap agama diyakini oleh pemeluknya mengajarkan sebuah kedamaian, toleransi, dan kasih sayang. Dalam Islam misalnya, dilarang keras untuk bersikap ekstrim (ghuluuw), menindas (djalim), sewenang-wenang dan melampaui batas. Sebaliknya Islam mengajak kepada umatnya untuk berlaku santun, toleransi, saling memaafkan, dan kasih sayang. Bahkan di antara agama-agama samawi yang ada, ajaran Islam merupakan jalan tengah (Madjid, 2000: 20 -23).

\section{HASIL DAN PEMBAHASAN}

Relasi Organisasi Mahasiswa Islam Kampus dan Strategi menangkal radikalisasi

Dalam perjalanan sejarah, banyak gerakan mahasiswa tumbuh di negeri ini termasuk diantaranya gerakan mahasiswa Islam. Hal ini menjadi bukti sejarah bahwasanya pergerakan mahasiswa Islam tidak dapat dipandang sebelah mata dalam mengawal perjalanan bangsa kita. Dan juga, dapat dikatakan gerakan mahasiswa islam menjadi energi yang konsisten dalam pergerakan mahasiswa di Indonesia. Terdapat beberapa organisasi mahasiswa Islam yang menonjol di kalangan akademisi kampus diantaranya HMI, PMII, KAMMI, dan IMM.

Organisasi-organisasi mahasiswa tersebut diatas merupakan suatu organisasi yang berlatar belakang kemahasiswaan yang berdiri diluar kampus, yang kemudian sering diidentikkan dengan organisasi ekstra kampus. Walaupun kedudukannya di luar lembaga kemahasiswaan kampus, organisasi ekstra turut berperan dalam pendampingan kebijakan-kebijakan yang dikeluarkan oleh kampus dan tidak boleh keluar dari rambu-rambu utama tugas dan fungsi perguruan tinggi yaitu Tri Dharma Perguruan Tinggi.

Tuntutan pengembangan kualitas sumber daya manusia, dalam hal ini mahasiswa menjadi salah satu prioritas dalam penyelenggraan pendidikan dewasa ini. Pengembangan pendidikan pergururan tinggi tidak bisa dilepaskan dengan prediksi perkembangan ilmu pengetahuan termasuk ilmu sosial humaniora, teknologi, seni budaya dan ekonomi budaya. Mahasiswa sangat dituntut berperan dalam membawa perubahan bangsa ke arah yang lebih baik serta dituntut untuk siap berkontribusi bagi masyarakat.

Organisasi mahasiswa ekstra kampus menjadi lahan produktif dalam mencetak kader yang mampu menyokong visi gerakan mahasiswa. Lebih dari itu, Organisasi mahasiswa ekstra kampus secara strategis juga mengendalikan arah gerakan mahasiswa dalam proses-proses demokrasi di kampus. Organisasi mahasiswa ekstra kampus tidak hanya mencetak intelektual, tetapi juga politisi handal. Bisa dikatakan, karir politik seorang mahasiswa dimulai dari organisasi mahasiswa ekstra kampus. Banyak kalangan berpandangan bahwa 
kehidupan kampus dan peran politik organisasi mahasiswa ekstra kampus merupakan miniatur dari konstelasi politik di Indonesia (Bisma, 2017: 94100). Hal inilah yang kemudian dianggap sebagian orang, mahasiswa yang aktif di luar kampus ada kecenderungan selain memiliki kemampuan dalam hal kebangsaan juga mendapatkan ideologi yang tidak menutup kemungkinan mengarah pada tindakan radikal.

Memperhatikan peran dan posisi organisasi mahasiswa ekstra kampus yang sangat dominan dalam kampus. Organisasi mahasiswa ekstra kampus juga dapat dianggap lahan yang sangat produktif tidak hanya dalam mencetak kader organisasi yang militan dan mampu menyokong ideologi organisasi. Lebih dari itu, organisasi mahasiswa ekstra kampus merupakan sirkuit Isu, pemikiran, dan kepentingan dari berbagai kekuatan di luar kampus. Sirkulasi Isu, pemikiran, dan kepentingan tersebut diduga memiliki kontribusi yang sangat besar (Bisma, 2017: 94-100).

Dalam perkembangannaya ada beberapa strategi yang dilakukan organisasi mahasiswa Muslim kampus dalam kaitannya menangkal radikalisme di kalngan mahasiswa, diantaranya :

\section{a. Kurikulum Kaderisasi Responsif Radikalisme}

Pada konsep ini dapat ditempuh melalui beberapa hal; pertama, Materi pendidikan deradikalisasi. Materimateri yang dimaksud dapat diterapkan pada seluruh kegiatankegiatan kaderisasi baik formal maupun informal. Seperti pada pelaksanaan MAPABA, PKD, LK dlsb. Tindakan paling solutif sesungguhnya adalah mengadakan materi pendidikan deradikalisasi secara mandiri. Tidak hanya diselipkan pada materi-materi kaderisasi yang lain. Sehingga secara epistimologis, konsep pemikiran dan aplikasi wawasan tangkal radikalisme dapat tertanam secara komprehensif; kedua, Pendidikan pancasila dan Pendidikan Agama. Bahwa yang telah berjalan selama ini juga tetap penting untuk dipertahankan yakni materi pendidikan pancasila dan pendidikan agama yang santun.

Ketiga, Mengembangkan materi diskusi kader yang berkaitan dengan cross-cultural undestanding (ccu). Menyusun kurikulum kaderisasi yang berpendakatan lintas budaya juga perlu dipertimbangkan. Sehingga pemahaman mahasiswa tidak cenderung primordial dan sektoral. Dengan pembelajaran yang mengarah pada tujuan untuk menghasilkan warga negara yang mempunyai sikap inklusif dan toleran terhadap kemajemukan masyarakat. Dalam praktiknya, pembelajaran dapat melibatkan nonMuslim supaya terjadi proses penanaman nilai-nilai pluralisme dan anti radikal di kalangan mahasiswa.

Keempat, Mentradisikan dialog. Konsep ini yang juga perlu terintegrasi dalam upaya menangkal radikalisme. Dialog atau sharing pemahaman dan pembelajaran iman baik pada agamanya sendiri maupun agama orang lain untuk bersama mengembangkan misi menciptakan perdamaian dan persaudaraan terutama di kalangan para pemeluk agama. Pendidikan ini tentunya sesuai dengan misi agama Islam yaitu rahmatan li al-'alamin, menebarkan berkah bagi seluruh masyarakat. Hasilnya tentu dapat meredam ketegangan-ketegangan yang seringkali muncul karena kesalah pahaman.

\section{b. Internalisasi Nilai-nilai Islam Ramah}

Internalisasi nilai-nilai Islam ramah dan santun juga harus menjadi kampanye yang penting untuk dilakukan. Selain dengan konsep kurikulum kaderisasi seperti diatas, juga perlu dibangun kesadaran bersama dari seluruh anggota organisasi. Membangun kesadaran 
perlu berangkat dari pemahaman keagamaan yang moderat dan kokoh. Hal inilah yang menjadi tugas kolektif institusional dan personal dalam membangun self awareness menuju collective awareness. Sehingga upaya penyadaran justru dapat dimulai dari gress root.

Media-media yang dapat digunakan untuk mengkampanyekan Islam ramah begitu melimpah. Selain melalui agenda diskusi-diskusi mingguan hingga bulanan, seminarseminar dan dialog, juga dapat dilakukan melalui khotbah atau ceramah-ceramah seminar ilmiah. Maksimalisasi peran senior sebagai model juga penting untuk diperhatikan. Senior tidak hanya bertindak memberi mauidhoh hasanah, melainkan uswatun hasanah.

\section{c. Kemitraan Perguruan Tinggi}

Jika selama ini organisasi ekstra kampus terkesan berseberangan dengan birokrasi kampusnya, adalah penting untuk dilakukan evaluasi. Kampus harus menjadi mitra strategis bagi organisasi ekstra pada upaya menangkal radikalisme. Menumpas perkembangan radikalisme agama di Indonesia ini tidak cukup dengan tembak mati, penjara seumur hidup, hukum gantung, akan tetapi harus melalui soft approach, salah satunya dengan mengandeng kemitraan melalui Perguruan Tinggi yang juga memiliki tanggung jawab dalam pembentukan keagamaan yang baik.

\section{d. Kemitraan dengan Pesantren}

Surakarta memiliki beragam pondok pesantren. Mengingat pertumbuhan pondok pesantren yang begitu pesat. Sebagai model pendidikan khas Indonesia, pesantren memegang peranan strategis dalam upaya menangkal pemahaman Islam radikal. Oleh karena itu, perguruan tinggi harus memikirkan untuk bekerjasama dengan pesantren, khususnya dalam agenda untuk menangkal radikalisme sekaligus dakwah Islam yang ramah.

Melalui model pembelajaran integratif di luar kelas. seperti kajian kitab kuning, mudzakarah, bahstul masail, istighosah, yasinan dan tahlil. Dengan demikian, mahasiswa tidak hanya mahir dalam kepasitas program studinya namun juga mampu mengamalkanya.

Selain itu relasi pesantren sangat erat dengan sentralitas peran Kiayi. Hal ini adalah bentuk penghargaan terhadap sanad keilmuan dan garis keturunan ulama panutan. Kebiasaan sowan Kiayi dan para guru penting untuk diterapkan dalam kehidupan sehari-hari. Karena melakukan pendidikan deradikalisasi tidak cukup hanya menceramahkanya di dalam kelas dan terpaku pada kurikulum. Lebih penting adalah menciptakan lingkungan yang anti terhadap praktikpraktik kekerasan atas nama agama, sehingga mereka dapat menjadi pribadi yang lebih toleran.

\section{e. Budaya Literasi Islam Santun}

Zaman milenial saat ini adalah era pertarungan gagasan dan pemikiran. Mahasiswa dan dosen wajib untuk produktif dalam menghasilkan narasi-narasi Islam yang santun dan toleran. Bukan saatnya lagi civitas akademika mengambil peran sebagai passanger, namun harus dirubah menjadi driver.

Aktor literasi dan gagasan adalah visi yang juga mesti dibangun untuk melakukan counter discourse terhadap narasi-narasi kebencian dan hoax. Dengan mentradisikan budaya diskusi, membaca, dan menulis akan menjadi senjata paling ampuh untuk menangkal radikalisme. Perguruan Tinggi harus memfasilitasi agenda-agenda kajian keilmuan, penulisan-penulisan dan penelitian yang responsif terhadap gerakan radikalisme dan terorisme. 


\section{PENUTUP}

Berdasarkan analisis data tentang nasionalisme organisasi ekstra kampus, maka dapat diambil kesimpulan sebagai berikut bahwasanya nasionalisme mahasiswa organisasi ekstra kampus dilakukan dalam bentuk kaderisasi formal dan non formal. Dalam kaderisasi formal masing-masing organisasi ekstra kampus memiliki jenjang sendiri-sendiri sesuai dengan AD/ART yang berlaku di organisasi tersebut. Organisasi-organisasi yang terlibat dalam penelitian ini yakni PMII, HMI, IMM, dan KAMMI. Gerakan yang dilakukan dalam organisasi ini bersifat massif, baik saat di luar atau di dalam kampus. Hanya saja, untuk kegiatan di dalam kampus masih terbentur dengan regulasi dan kebijakan institusi sehingga membuat organisasi internal kampus terbatas dalam melakukan kegiatan.[]

\section{DAFTAR RUJUKAN}

Al-Qurtuby, Sumanto. Jihad Melawan Ekstremis Agama, Semarang: Borobudur Indonesia Publishing. 2009.

Bisma, Ginanjar Gesang Bayu. "Organisasi Mahasiswa Ekstra Kampus Islam di Universitas Airlangga (Pandangan Tentang Wacana Prospek Demokrasi dan Relasi Negara Agama)." Jurnal Politik Muda 6.2 (2017): 94-100.

Buchor, Muchtar. "Radikalisme Agama; Sebuah Catatan Awal." Jurnal Pesantren, 4,3 (1986).

Depdiknas RI, Pusat Bahasa. Kamus Bahasa Indonesia, Jakarta: Pusat Bahasa Depdiknas, 2008.

Fadjar , Abdullah dkk., Laporan Penelitian Islam Kampus, Jakarta: Ditjen Dikti Depdiknas, 2007.

Haryono, M. Yudhie. Memaafkan Islam, Jakarta: Kalam Nusantara. 2006.

Junanto, Subar. Civic Education, Surakarta: Fataba Press, 2013.
Kartodirdjo, Sartono. Ratu Adil, Jakarta: Sinar Harapan. 1985.

Madjid, Nurcholish. "Metodologi dan orientasi Studi Islam Masa Depan." Jauhar; Jurnal Pemikiran Islam Kontemporer 1.1 (2000): 20-23.

Masykur, Ali. Nasionalisme di Persimpangan pergumulan $N U$ dan Paham Kebangsaan Indonesia, Jakarta: Erlangga, 2011.

Saifuddin. "Radikalisme di Kalangan Mahasiswa, Sebuah Metamorfosa Baru." Analisis Jurnal Studi KeIslaman XI.1 (2011).

Shihab, M. Quraish. Tafsir al Misbah, Jakarta: Lentera Hati, 2012. 